\title{
CONSTRUCTION OF CORPORATE SOCIAL RESPONSIBILITY (CSR) DISCLOSURE INDEX AND ITS PRACTICES BY LISTED COMPANIES IN OMAN
}

\author{
Afshan Younas \\ Faculty of Business Studies \\ Arab Open University, Muscat, Oman \\ E-mail: afshan@aou.edu.om \\ Aza Azlina Md Kassim \\ Faculty of Economics and Management \\ Xiamen University Malaysia, Malaysia \\ Abul Bashar Bhuiyan \\ Faculty of Business \& Accountancy \\ University of Selangor, Malaysia
}

\begin{abstract}
The importance of Corporate Social Responsibility has been acknowledged greatly as an objective of business sustainability. Whereas the measurement of CSR is always a source of argument among researchers. There are different approaches identified and used by researchers to measure CSR. The main objective of this study is to measure CSR disclosure by constructing an index based on content analysis. The study used the data of non-financial listed companies' annual reports to construct an index for the period 2016, 2017, 2018, and 2019. Thus, 291 firmyear observations are used in this study to construct and measure the CSR disclosure index. 40 elements are used to measure CSR disclosure based on five sub-themes. The result of the study reveals that as CSR disclosure requirement is mandatory in Oman according to the new corporate governance system, thus the listed companies are trying to cope and developing CSR charters. The evidence indicates that some companies have high CSR disclosure while few companies are still struggling with developing CSR charter and disclosing their activities. However, CSR disclosure improves significantly from 2016 to 2019, which shows a strict implementation of the code of corporate governance.
\end{abstract}

Keywords: CSR Disclosure, Content Analysis, Workforce, Community Welfare.

\section{INTRODUCTION}

Corporate social responsibility is considered a sustainable tool for business operations. Corporate social responsibility has several impacts on the corporate image (Harun et al. 2020). The success of a company is measured in many terms, which include attaining the expectations of stakeholders, mainly shareholders. The shareholders are keenly interested in the financial performance of the company and its operations. The financial performance of the company can be improved through transparency of the company's operational activity (Supriyati and Hudiwinarsih 2020). Thus, corporate social responsibility (CSR) occupies an essential place in 
the operating activities of any business performance. Corporate social responsibility also pushes the competitive advantage and improves the business reputation to the society (Doda 2015).

Another important indicator that shows the increasing importance of corporate social responsibly is the increasing research in the area of academic research as well as the voluntary adoption and disclosure of corporate social responsibility activities (Tilakasiri 2015). Despite the growing concern of corporate social responsibility practices in business, disclosure is the main area where researchers suggest different approaches and areas of corporate social responsibility measurements. Hence, measuring corporate social responsibility is a unique area of study which is mostly covered in developed countries but developing countries are still less explored (Ehsan et al. 2018). Gulf Cooperation Council (GCC) countries have distinctive traits as compare to the western world, and corporate social responsibility is considered as one of the religious duties in these countries (Issa 2017). Oman is the member country of GCC countries and holds a prominent position. Oman is the first among all GCC countries who adopted and implemented the code of corporate governance in 2002. The updated and current version of code of corporate governance code was developed in 2015 and implemented in 2016 (CMA 2016). According to this latest code of corporate governance, which is based on fourteen principles, corporate social responsibility is the thirteenth important principle, which highlights the importance of CSR for all listed companies and abide them to disclose their CSR activities.

The measure of CSR is an imperative and most challenging task in conducting CSR research. CSR is a multidimensional notion and measuring this multidimensional approach is complicated and difficult. Also, it is highly desired to cover all the dimensions of CSR to show more accurate, reliable, and valid measurement instruments (Tilakasiri 2015). Many studies proposed different ways of measuring CSR and suggest different areas of CSR concept which covers, sustainability, environment, workforce, products, customers, and general social welfare. Thus, this study focuses on constructing a CSR disclosure index based on a content analysis approach on the public listed companies in Oman from 2016 to 2019.

\section{LITERATURE REVIEW}

The concept of corporate social responsibility has existed for several decades before, but the term corporate social responsibility was officially introduced by American economist Howard Bowen in 1953 in his publication 'Social Responsibilities of the Businessman' (Diez-Cañamero et al. 2020). Bowen is considered as the father of CSR notion and defined it as the group of responsibilities and commitments of employers related to the adoption of policies and the development of lines of action that respond to the values and desires of society (Carroll 2009).

Later, in the 1960s, the concept of CSR was further explained and justified by Davis as a long-run economic gain of the firm tool. Also, the term stakeholders emerged to refer to those who had a legitimate interest in the business. This tenure exposes an in-depth relationship between companies, society, and all those stakeholders that could be affected by the actions of companies. The introduction of this notion entails the inclusion in the business environment of ethical aspects along with other moral and philosophical aspects (Phillips, Schrempf-Stirling, and Stutz 2020). In the 1970s, the business environment of ethical aspect coexists with other distinctive factors, that is, the maximization of results, and a unique responsibility towards the shareholders. At this stage, the consideration of the owner or responsible accountable individuals initiated to open to the concept of corporate responsibility that already considering businesses as responsible entities and capable of acquiring commitment as 'good corporate citizens' (DiezCañamero et al. 2020). 
During the 1980s, another substantial transformation was initiated in the notion of CSR, as it was recognized as an area that needed to be planned, managed, and controlled, like other aspects of the business operations. Companies started to analyze the social outcomes of their CSR decisions. In this period, CSR is highly linked to actions taken as a form of proactive approach instead of negligent or reactive ones (Cochran and Wood 1984).

In the next decade, the 1990s, many business institutes introduced ethical education to train the entrepreneurs, thus business ethics became a subject of research and interest for academics (Donaldson and Dunfee 1994). Researchers initiated to explore the different factors that influence the ethical conduct in a business, distinguishing those that affect the decisionmakers. In this perspective, age, gender, ethnicity, education, religion or personality, and other situational factors such as the environment sector, the competitiveness of the industry, the codes of conduct, or the industry and country factors are considered fundamental characteristics. In 1991, Wood has developed an institutional framework that is based on four types of corporate responsibilities such as economic, legal, ethical, and philanthropic (Latapí Agudelo, Jóhannsdóttir, and Davídsdóttir 2019).

The $21 \mathrm{~s}$ century is characterized by the integration and interaction of commercial and financial relations that suggests constant changes in the economic and social environment. Thus, CSR becomes an important corporate decision that affects both sustainability and stakeholders. Three areas of CSR have been identified as an important domain of the CSR approach which includes economic, social, and environmental. The economic areas of CSR have developed from the sole obligation of accountability of shareholders and analyzing the influence of actions on the financial performance of the business. It also covers other aspects such as the workforce, innovation, product, and service developments (Jamali 2008). The social area is related to human resources, including internal and external to the business environment as well as all social aspects of the business stakeholders. The environmental area refers to the obligation of companies to take care of the environment, understanding and promoting awareness of environmental issues in obtaining sustainable developments and taking business influences into account that have an impact on climate change (Diez-Cañamero et al. 2020).

The CSR term is broader and there is no specific definition. Many businesses follow CSR as a form of self-regulation system where the CSR activities and their disclosure is voluntary whereas businesses also follow CSR activities and disclose them where it is mandatory by the laws or country-specific codes. Thus, the notion of CSR is wider and as passes time many activities and actions are added to the literature of CSR.

\section{Review of Existing Approaches and Constructing Index}

CSR activities demonstrate that businesses, which take an interest in wider social issues will enable them to attract more customers, investors, and develop a highly positive corporate image. Whereas, measuring CSR activities is extremely important as it enables stakeholders to improve their decisions as customers, investors, managers, regulators, and all other internal and external stakeholders (Szegedi, Khan, and Lentner 2020). Several approaches are used by researchers to measure CSR activities. The most conventional approaches are content analysis, reputational indices, questionnaire-based survey, and one-dimensional approach. Among these four approaches, the most common and widely approach used by many researchers is content analysis. 
The content analysis approach is based on secondary data sources that mainly include the information published by firms through annual reports and its website. The information is collected and then transferred into a quantitative form to develop a disclosure index (Ehsan et al. 2018). Whereas, under the reputation indices approach the CSR is measured by specialized private rating agencies according to country-specific codes and their measurement bases (Johansson, Karlsson, and Hagberg 2015). However, the questionnaire-based survey method is usually suggested and used by the researcher when information about business's CSR disclosure is not sufficiently available through secondary sources (Galant and Cadez 2017). Another important approach is the one-dimensional approach, which focuses on a single dimension of CSR, and usually focuses on the environmental side of a firm's CSR disclosure. All these four approaches are extensively used by researchers, but the content analysis approach is heavily used in measuring CSR disclosure (Ehsan et al. 2018; Omair Alotaibi and Hussainey 2016; Szegedi et al. 2020).

The current study used a content analysis approach to develop and measure the CSR disclosure index. The content analysis approach is also known as the disclosure approach to measuring corporate social responsibility as a qualitative approach (Milne and Adler 1999). Under content analysis two methods are commonly known are used, one is 'index' and another is 'volumetric'. In the 'index' method the presence and absence of specific items are checked by following a binary coding method. If specific item presents, assign 1, and if a particular item is missing then assign 0 . Whereas, the volumetric method focuses on the volume of a particular item in the selected text, such as counting words, sentences, paragraphs, and pages (Kansal, Joshi, and Batra 2014).

Under content analysis, it is imperative to identify and indicate the appropriate unit of analysis that supports the objective of the study. Another important consideration under content analysis is the selection of categories in which context units are classified and develop the index. The current study has used the index which is proposed and developed by Ehsan et al. (2018), whereas minor modifications and amendments have been made to fit with the country's requirements. The CSR index is based on five sub-themes which comprise 40 items (Appendix A). General community welfare, health and education, environment and energy, product and customer and stakeholders, and workforce are the five sub-themes of the CSR disclosure index. There are 11 items under general community welfare, 5 items under health and education, 7 items under environmental and energy, 9 items under product and customer, and finally 8 items under workforce. These five sub-themes which comprise 40 items also reflect the sustainability development goals which are identified by the United Nations and comprised of 17 goals (UN 2021). However, to fit with the country requirement minor modifications are made based on Oman code of corporate governance (2016). The reliability of the CSR disclosure index is reported by Ehsan et al. (2018) as Cronbach's coefficient alpha value of 0.924 , which is considered outstanding in accepting five sub-themes with 40 items.

In this study, the CSR index has been calculated separately for each sub-theme and then the total index has been calculated dividing by a total of 40 items and calculated from 100 as a percentage. The scoring approach is essentially dichotomous, assigning 1 as the item is present and assigning 0 if the item is absent. Thus the CSR index is calculated as:

$C S R I=\frac{\sum x_{i j}}{n_{j}}$

$C S R I=$ Corporate Social responsibility index of $j^{\text {th }}$ company 
$n_{j}=$ Total number of CSR items

$x_{i j}=1$ if “ $i$ " " item is disclosed by $j^{\text {th }}$ company's annual reports or website, and 0 if the item is not disclosed

\section{Sample Size}

The current study used annual reports of the non-financial listed firms on Muscat Securities Market for the period of four years from 2016 to 2019. The rationale to use years from 2016 to 2019 is due to the introduction and implementation of the latest code of corporate governance in Oman in 2016, and also the available data for analysis is till 2019 annual reports. Thus, 291 firmyear observations are used in this study to construct and measure the CSR disclosure index for four years.

\section{RESULTS AND FINDINGS}

The descriptive results of CSR by year are given in Table 1. The average value of the overall CSR disclosure index for four years of 291 firm's year observation is $42.15 \%$ which shows that CSR disclosure of Omani listed firms is less average and still the firms are at the developing stage of CSR charter. Whereas, the four years trend shows increasing awareness of CSR activities and disclosure as can be seen in Table 1 . The average value of CSR disclosure of listed firms in 2016 is 39.63\%. Whereas in 2017 the average value of CSR disclosure is increased and reached $41.92 \%$. The increasing trend has been followed in 2018 and 2019, the average value of CSR disclosure in 2018 is $42.89 \%$ and in 2019 is $43.95 \%$. This increasing tendency of CSR disclosure is a good sign for public listed companies at Muscat Securities Market. Also, an increase in CSR disclosure confirms an effective implementation of the current code of corporate governance in Oman. The results also confirm the growing realization of CSR activities and their importance. This study confirms the results of Ehsan et al. (2018), which also shows the increasing trend in CSR disclosure on yearly basis.

According to the current code of corporate governance, all listed companies are abiding by the law to develop CSR charter and disclose their CSR activities in annual report or company website (CMA 2019). In response to the thirteenth principle of the code of corporate governance in Oman, several public companies have developed CSR charter and practicing CSR activities. Whereas there are still some companies that are struggling to develop CSR charter and cope with the changes, as it can be seen from Table 1, with the minimum value of CSR yearly, however, the maximum value of CSR shows a positive tendency of adoption of CSR practices by listed companies.

Table 1. Descriptive Statistics of CSR by year

\begin{tabular}{|l|l|l|l|l|l|l|}
\hline Variables & Symbol & Mean & Median & SD & MIN & MAX \\
\hline $\begin{array}{l}\text { Corporate } \\
\text { Social } \\
\text { Responsibility }\end{array}$ & CSRI & 42.15 & 43.00 & 17.16 & 0 & 93.00 \\
\hline 2016 & & 39.73 & 38 & 17.42 & 0 & 90.00 \\
\hline 2017 & & 41.92 & 43 & 16.97 & 0 & 90.00 \\
\hline 2018 & & 42.89 & 44 & 17.33 & 0 & 93.00 \\
\hline 2019 & & 43.95 & 45 & 17.01 & 0 & 93.00 \\
\hline
\end{tabular}


The descriptive statistics of CSR by sub-indices are given in Table 2. From 2016 to 2019 the mean value of Community welfare is $32.33 \%$, Education and Health are 22.40, Environment and Energy are $18.14 \%$, Product and Customer is $68.37 \%$, and workforce is $53.21 \%$. Among the sub-indices, the highest mean value is for the Product and Customer index, which is $68.37 \%$. This indicates that companies in Oman are mostly focused on disclosure on product and customer aspect of CSR. The second highest mean value is reported by the workforce index which is $53.21 \%$. This result shows that firms in Oman are keen to focus on internal CSR which also fulfills the requirement of the Ministry of Manpower Law as Omanisation and hiring local talents. The result of the Product and Customer and Workforce indices are consistent with the study of Ehsan et al. (2018), which also reveals that companies mostly focused and disclosed on the Product and Workforce aspect of CSR.

Table 2. Descriptive Statistics of CSR by Sub-Indices

\begin{tabular}{|l|l|r|r|r|r|r|}
\hline Variables Symbol & Mean & Median & SD & MIN & MAX \\
\hline $\begin{array}{l}\text { Corporate Social } \\
\text { Responsibility }\end{array}$ & CSRI & & & & & \\
\hline Community Welfare & & 32.33 & 36.36 & 21.06 & 0 & 90.91 \\
\hline Education \& Health & & 22.40 & 20.00 & 26.97 & 0 & 100 \\
\hline $\begin{array}{l}\text { Environment \& } \\
\text { Energy }\end{array}$ & & 18.14 & 14.29 & 25.42 & 0 & 100 \\
\hline Product \& Customer & & 68.37 & 77.78 & 21.63 & 0 & 100 \\
\hline Workforce & & 53.21 & 50.00 & 27.16 & 0 & 100 \\
\hline
\end{tabular}

Similarly, the community welfare index stands at the third highest mean value as $32.33 \%$, but this value is below the average value which reflects the firms' involvement in community and socially-oriented activities. The Education and Health index stands at fourth position with the mean value of $22.40 \%$. This result indicates that the education sector and health sector are still weak and ignored in Oman even after placing considerable efforts in recent years. The Environment and Energy index stands at the fifth and last place with the mean value of 18.14\%, this figure reveals that a firm's commitment to the environment and energy aspect of CSR is very less. This less engagement is due to the high involvement of governmental organizations in the energy sector, where all major resources are planned and controlled by governmental organizations.

The descriptive statistics of CSR disclosure by industry are given in Table 3. There is a total of 16 types of industries operating and listed at Muscat securities Market. The highest CSR disclosure index is reported in Telecommunication Industry as 61\%, which is composed of only two firms. The second highest CSR disclosure index is 53\% which is reported in the Electrical Industry, which is also composed of two firms. Other industries have also a great share in CSR disclosure, the Energy Industry with a mean value of 54\%, and the Cement Industry with a mean value of $49 \%$. Further, it is followed by the Engineering Industry with the mean value of $43 \%$, the Logistics Industry with a mean value of $45 \%$, the Education industry with a mean value of $46 \%$, Commercial Services Industry with a mean value of $43 \%$, Tourism Industry with a mean value of $41 \%$, and Textiles industry with a mean value of $39 \%$ as mentioned in Table 3. 
Table 3. Descriptive Statistics of CSR Disclosure by Industry

\begin{tabular}{|l|l|l|l|l|l|l|}
\hline Sectors & N & Mean & Median & SD & MIN & MAX \\
\hline Cement Industry & 2 & 49 & 49 & 16 & 33 & 65 \\
\hline Chemicals Industry & 3 & 40 & 41 & 14 & 13 & 60 \\
\hline Commercial Services Industry & 4 & 43 & 39 & 35 & 0 & 93 \\
\hline Construction Material Industry & 7 & 37 & 38 & 12 & 10 & 63 \\
\hline Education Industry & 2 & 46 & 48 & 3 & 40 & 48 \\
\hline Electrical Industry & 2 & 53 & 53 & 4 & 48 & 58 \\
\hline Energy Industry & 11 & 54 & 57 & 11 & 28 & 73 \\
\hline Engineering Industry & 2 & 43 & 46 & 11 & 20 & 55 \\
\hline Food Industry & 14 & 40 & 43 & 13 & 18 & 58 \\
\hline Logistics Industry & 1 & 45 & 45 & 0 & 45 & 45 \\
\hline Mining Industry & 3 & 25 & 24 & 7 & 18 & 35 \\
\hline Oil and Gas Industry & 5 & 50 & 52 & 12 & 25 & 78 \\
\hline Paper \& Glass Industry & 3 & 24 & 26 & 8 & 13 & 35 \\
\hline Telecommunication Industry & 2 & 61 & 60 & 15 & 43 & 80 \\
\hline Textiles industry & 1 & 39 & 39 & 1 & 38 & 40 \\
\hline Tourism Industry & 5 & 41 & 37 & 16 & 18 & 70 \\
\hline
\end{tabular}

The reason for higher CSR disclosure in the Telecommunication industry, Electrical industry, Energy industry Cement industry, Engineering industry, Logistics industry, Education industry, and Commercial industry is root back in their higher capitalization of Muscat Securities Market. These industries have more resources to practice their CSR activities and reporting them effectively in their annual reports. On the other hand, the least CSR disclosure is reported in the Mining industry which is $25 \%$, and the Paper and Glass industry which is also $24 \%$. This reflects that the Minding industry, and Paper and Glass industry discloses the least amount of information than all other industries.

\section{DISCUSSION}

The result of the study indicates that CSR practices and their disclosure in Oman show the commitment of businesses and the execution of the code of corporate governance by Capital Market Authority (CMA) Oman. Overall, the listed firms in Oman show $42.15 \%$ of CSR disclosure from 2016 to 2019, which reflects the significant contribution and efforts done by several firms. The result of five sub-indices shows that businesses are involved in practicing and disclosing more information of product and customer aspect of CSR which is $68.37 \%$ and workforce that reflects the internal aspect of CSR which is $53.21 \%$. A possible reason for high disclosure of product and customer aspect of CSR is due to firms' certification of ISO 9000, which is an international system of quality management that companies need to maintain in order to compliance the law (Bashir, Alzebdeh, and Rashid 2008). The workforce aspect of CSR is the second-highest sub-index. The reason for higher CSR score is due to stringent rules and laws by the Ministry of Manpower in Oman, which requires all firms to disclose their workforce details and to support the local talent and fill the gap of unemployment, follow and implement Omanisation law (Al-balushi 2018). On the other hand, less CSR disclosure is evident in the sub- 
index of Environment and Energy. This is due to less recognition of the importance of environment and energy sources by the listed firms. The population of Oman is approximately 4 million which is less as compared to developing countries. Thus energy is not the main concern till 2012 due to the availability of sufficient natural reserves which includes oil and petrochemical products (Mawali, Hasim, and Al-Busaidi 2016). Similarly, the issues related to the environment are not at very high risk as compare to developing countries, thus the CSR activities and disclosure is evident less in these indices. These findings are significant in the context of GCC countries and particularly in the context of Oman, which portrays that CSR activities are gaining importance and which sub aspects of CSR are still underdeveloped and ignored.

The findings of this study offer important implications for a range of stakeholders, like regulators, policymakers, the board of directors, investors, and the public. The study offers a broad framework for constructing an index of CSR disclosure. This provides fruitful insight to Capital Market Authority (CMA) in Oman about the practical adoption and implementation of code of corporate governance principles for four years through which they can further formulate and implement rigorous plans. Since the CSR practices and disclosure is the thirteenth principle of the Oman code of corporate governance, thus these results offer an understanding of listed companies' compliance to the code. The policymaker can adopt more stringent practices to enhance and assure the CSR practices by the firm (Lu and Abeysekera 2021). Likewise, the current study provides industry-wise CSR disclosure which is useful to monitor industry trends by the industry experts and specialists. In addition, the board of directors can use the result of this study to benchmark their performance with the industry. Similarly, this study offers a significant understanding of CSR practices and its disclosure of listed companies in Oman to the general public to buy goods from socially responsible firms and promote CSR-oriented companies (Axjonow, Ernstberger, and Pott 2018). This is the first kind of empirical study in Oman which developed a comprehensive scale for the measurement of CSR in Oman comprised of 40 elements, which also comply with the seventeen sustainable development goals identified by the United Nations.

This study has few limitations as well as offering new openings for future research areas. First, the data used in this study is collected from annual reports of firms which is available on the Muscat Securities Market (MSM) website. But in reality, management also uses other sources of mass communication, such as newspapers, websites, and magazines to disclose their CSR activities, which is not included in this study. Secondly, the study collected data only for non-financial listed companies, whereas the CSR activities of financial listed companies are not covered in this research. Thus, future studies can consider the above limitations as an opportunity to pursue research in the same area.

\section{CONCLUSION}

The main objective of the current study is to fill the gap in the literature of constructing an index of CSR disclosure of listed companies at Muscat Securities Market from 2016 to 2019. The study provides a better understanding of CSR practices and their disclosure using the case of Oman. The study fulfils the main objective of constructing an index of CSR disclosure practices in Oman. The content analysis approach has been adopted for 291 firm-year observations for a period of four years from 2016 to 2019. Since CSR disclosure is considered mandatory for public listed companies thus this study portrays the implementation of the code of corporate governance in Oman. The CSR disclosure index has been constructed on the basis of five sub-indices which 
are established on 40 elements. The result of the study indicates that non-financial listed companies have high CSR disclosure in the Product and Customer index, which is followed by the Workforce index. Whereas the least CSR disclosure is evident in Environment and Energy index. The evidence indicates that some companies have high CSR disclosure while few companies are still struggling with developing CSR charter and disclosing their activities. However, CSR disclosure improves significantly from 2016 to 2019, which shows a strict implementation of the code of corporate governance.

Conflicts of Interest: The authors declare no conflict of interest

\section{REFERENCES}

Al-balushi, Masooma. 2018. "Issues Affecting Omanization of the Hotel Sector." 6(2):164-77. doi: 10.15640/jns.v6n2a14.

Axjonow, Anastasia, Jürgen Ernstberger, and Christiane Pott. 2018. "The Impact of Corporate Social Responsibility Disclosure on Corporate Reputation: A Non-Professional Stakeholder Perspective." Journal of Business Ethics 151(2):429-50. doi: 10.1007/s10551-016-3225-4.

Bashir, Hamdi A., Khalid Alzebdeh, and Maki K. Rashid. 2008. "Survey Results on Knowledge, Perception and Attitude of Consumers towards ISO 9001:2000 Quality Management Standards." in IIE Annual Conference and Expo 2008.

Carroll, Archie B. 2009. "A History of Corporate Social Responsibility: Concepts and Practices." The Oxford Handbook of Corporate Social Responsibility (January 2008). doi: 10.1093/oxfordhb/9780199211593.003.0002.

CMA. 2016. Code of Corporate Governance for Public Listed Companies (The "Code”).

CMA. 2019. "Capital Market Authority, Sultanate of Oman - Capital Market Development Phases." Cma.Gov. Retrieved June 2019 (https://www.cma.gov.om/Home/Page/NotavailableinEN1).

Cochran, Philip L., and Robert A. Wood. 1984. "Corporate Social Responsibility and Financial Performance." The Academy of Management Journal 27(1):42-56. doi: 10.2307/255956.

Diez-Cañamero, Borja, Tania Bishara, Jose Ramon Otegi-Olaso, Rikardo Minguez, and José María Fernández. 2020. "Measurement of Corporate Social Responsibility: A Review of Corporate Sustainability Indexes, Rankings and Ratings." Sustainability (Switzerland) 12(5). doi: 10.3390/su12052153.

Doda, Sanie. 2015. "The Importance of Corporate Social Responsibility." Journal of Sociological Research 6(1):86-91. doi: 10.5296/jsr.v6i1.7426.

Donaldson, Thoman, and Thomas W. Dunfee. 1994. "Towards a Unified Conception of Business Ethics: Integrative.” The Academy of Management Review 19(2):252.

Ehsan, Sadaf, Mian Sajid Nazir, Mohammad Nurunnabi, Qasim Raza Khan, Samya Tahir, and Ishfaq Ahmed. 2018. "A Multimethod Approach to Assess and Measure Corporate Social Responsibility Disclosure and Practices in a Developing Economy." Sustainability (Switzerland) 10(8). doi: 10.3390/su10082955.

Galant, Adriana, and Simon Cadez. 2017. "Corporate Social Responsibility and Financial Performance Relationship: A Review of Measurement Approaches." Economic ResearchEkonomska Istrazivanja 30(1):676-93. doi: 10.1080/1331677X.2017.1313122.

Harun, Mohd Shukor, Khaled Hussainey, Khairul Ayuni Mohd Kharuddin, and Omar Al Farooque. 2020. "CSR Disclosure, Corporate Governance and Firm Value: A Study on GCC Islamic Banks.” International Journal of Accounting and Information Management 
28(4):607-38. doi: 10.1108/IJAIM-08-2019-0103.

Issa, Ayman I. F. 2017. "Australian Journal of Basic And Applied Sciences The Factors Influencing Corporate Social Responsibility Disclosure in the Kingdom of Saudi Arabia." Australian Journal of Basic and Applied Sciences Aust. J. Basic \& Appl. Sci 11(1110):1-19.

Jamali, Dima. 2008. "A Stakeholder Approach to Corporate Social Responsibility: A Fresh Perspective into Theory and Practice." Journal of Business Ethics. doi: 10.1007/s10551007-9572-4.

Johansson, Sebastian, Anton Karlsson, and Christian Hagberg. 2015. "The Relationship between CSR and Financial Performance -A Quantitative Study Examining Swedish Publicly Traded Companies." Linnaeus University Sweden 7(May):51-58.

Kansal, Monika, Mahesh Joshi, and Gurdip Singh Batra. 2014. "Determinants of Corporate Social Responsibility Disclosures: Evidence from India." Advances in Accounting 30(1):217-29. doi: 10.1016/j.adiac.2014.03.009.

Latapí Agudelo, Mauricio Andrés, Lára Jóhannsdóttir, and Brynhildur Davídsdóttir. 2019. "A Literature Review of the History and Evolution of Corporate Social Responsibility." International Journal of Corporate Social Responsibility 4(1):1-23. doi: 10.1186/s40991018-0039-y.

Lu, Yingjun, and Indra Abeysekera. 2021. "Do Investors and Analysts Value Strategic Corporate Social Responsibility Disclosures? Evidence from China." Journal of International Financial Management and Accounting. doi: 10.1111/jifm.12126.

Mawali, Nasser, Haslifah Mohamad Hasim, and Khalil Al-Busaidi. 2016. "Modeling the Impact of the Oil Sector on the Economy of Sultanate of Oman." International Journal of Energy Economics and Policy 6(1).

Milne, Markus J., and Ralph W. Adler. 1999. "Exploring the Reliability of Social and Environmental Disclosures Content Analysis." Accounting, Auditing \& Accountability Journal 12(2):237-56. doi: 10.1108/09513579910270138.

Omair Alotaibi, Khaleed, and Khaled Hussainey. 2016. "Determinants of CSR Disclosure Quantity and Quality: Evidence from Non-Financial Listed Firms in Saudi Arabia Oa." International Journal of Disclosure and Governance 13(4):364-93. doi: 10.1057/jdg.2016.2.

Phillips, Robert, Judith Schrempf-Stirling, and Christian Stutz. 2020. "The Past, History, and Corporate Social Responsibility." Journal of Business Ethics 166(2):203-13. doi: 10.1007/s10551-019-04319-0.

Supriyati, and Gunasti Hudiwinarsih. 2020. "The Importance of Corporate Social Responsibility in Improving Corporate Value: Case Study of Public Companies in Indonesia." International Journal of Finance \& Banking Studies (2147-4486) 9(3):121-30. doi: 10.20525/ijfbs.v9i3.868.

Szegedi, Krisztina, Yahya Khan, and Csaba Lentner. 2020. "Corporate Social Responsibility and Financial Performance: Evidence from Pakistani Listed Banks.” Sustainability (Switzerland) 12(10):1-19. doi: 10.3390/SU12104080.

Tilakasiri, K. K. 2015. "Construct an Index for Measuring Corporate Social Responsibility Activities for Developing World : Evidence from Sri Lanka.” 4(7):608-12.

UN. 2021. "Take Action for the Sustainable Development Goals - United Nations Sustainable Development."

Retrieved

March

18

2021 (https://www.un.org/sustainabledevelopment/sustainable-development-goals/). 


\section{APPENCIES}

\section{Table A1. Checklist of CSR disclosure themes/items}

\section{1: Community Welfare (11)}

1.1

1.2

1.3

1.4

1.5

1.6

1.7

1.8

1.9
Acknowledgment of CSR and Development of CSR Charter

Disclosures about corporate objectives or CSR policies

Donations for flood-affected people and earthquake affected people

Donations for SME development

Donations for internally displaced people (IDPs), Donations for disable people

Donations by employees for affected people

Rural development programs and Local area development

Women's empowerment and development program

Sponsoring and donations to various sports activities, national and international games, events, and religious activities

Assistance to different trusts and ministries

Other general community welfare activities

\section{2: Contribution to Education and Health Sector (5)}

Donation to different schools, colleges, and universities for educational facilities

Scholarships to poor students

Sponsoring or organizing different educational activities

Provision of healthcare services

Donations for different hospitals to run their operations

\section{3: Environmental and Energy Importance (7)}

Environmental protection (improvement or awareness)

Pollution prevention or carbon emission control

Waste management or minimized water consumption

Implantation of trees and green issues

Energy efficiency, and reduced energy consumption

Utilizing waste materials or other sources for energy production

Investment in energy projects

\section{4: Product/Services and Customers (9)}

Explanation of major kinds of product/services

Product or service quality, quality-control system, and procedures

Product or service, Research and Development, and product improvements

Product or production process safety

Value-added statement

Statement of ethics and business practices or code of ethics/statement of internal control

Stakeholder approach

Risk management committee/practices

Disclosing information about customer service 


\section{$5.1 \quad$ Employee training \\ 5.2 Number of employees \\ 5.3 Career-development programs \\ $5.4 \quad$ Employee benefits \\ 5.5 Employee satisfaction/job sustainability \\ 5.6 Compensation plan or policy for employees \\ 5.7 Providing a safe, working environment to employee \\ 5.8 Employment of Omani employees (Omanisation)}

\section{Copyrights}

Copyright for this article is retained by the author(s), with first publication rights granted to the journal. This is an open-access article distributed under the terms and conditions of the Creative Commons Attribution license (https://creativecommons.org/licenses/by/4.0). 